\title{
A Value-Based and Multi-Level Model of Macro Economies
}

\author{
Marcel van Marrewijk \\ Van Linden van den Heuvellsingel 7, Vlaardingen, the Netherlands \\ E-mail:marcel@vanmarrewijk.nl \\ Received December 22, 2009; revised January 2, 2010; accepted January 20, 2010
}

\begin{abstract}
There is sufficient evidence that performance levels of various economic systems differ. All systems seem to have particular benefits, but all of them are adequately aligned with the dynamics and complexity of contemporary societies. In this paper, the author introduces a sequence of ideal type economic systems, based on Spiral Dynamics, a theory explaining levels of existence within people, groups of people, organizations and societies. Per type the author elaborates on the underlying value systems and relating institutional structures, such as leadership style, governance and measurement format.
\end{abstract}

Keywords: Value Systems, Economic Systems, Spiral Dynamics, Plan Economies, Capitalist Economies, Social Market Economies, Interdependent Economies

\section{A 'Multiple Level-View" on European Economies}

Since the conclusion of the Lisbon European Council of 2000, one of the challenges for the European Union has been "to become the most competitive and dynamic knowledge-based economy in the world, capable of sustaining economic growth, with more and better jobs, and greater social cohesion". This ambition challenge Europeans to seek a convergence between competitiveness and the quality of working life for employees, as the basis for promoting employee commitment, unleashing of organizational initiatives and the development of personal potential.

The actual breakthrough in formulating this challenge lies in the conceptual notion of economic development: thinking in terms of "and" in stead of "or". Not seeking economic growth at the expense of people and planet, but striving to create a synergy by enhancing the quality of jobs and launching social innovations in order to support economic growth. Labor has become an asset, not just a resource.

The European Commission's Directorate General (DG) for Employment, Social Affairs \& Equal Opportunities launched the European Union (EU) Work Climate project to stimulate co-operative research and to promote the exchange of opinions and experiences between the parties actively involved in industrial relations, about:

- Working conditions in Europe from a comparative perspective based on the results of a study commissioned by the EU.
- How European workers compare their employment conditions in the companies were they work.

- European wide trends and single out benchmarks for different models of employment relations

- Whether there is a link between quality of work and productivity? If improvements in work climate and working conditions, increase the quality and efficiency of investment in human capital and does it translates into productivity gains?

The DG regards this social dialogue as the driving force behind successful economic and social reforms.

The DG granted this EU Work Climate project to the Institute of Labor Studies (IEL) at ESADE Business School. The fundamental aim of this project is to conduct a comparative analysis amongst 14 member countries based on standardized data pertaining to employment conditions supplied by Great Place to Work ${ }^{\circledR}$ Institute Europe. The latter has developed over the years a methodology (standardized instruments and sampling procedures) for data collection enabling them to choose the "best company to work for" in each country. The data bank includes information provided by employees and managers in over 2,500 companies in $14 \mathrm{EU}$ member states in three consecutive years (2003-2005). The IEL gathered an international team of experts specialized in secondary data analyses of the Great Place to Work ${ }^{\circledR}$ data bank in order to identify trends and benchmark cases. Please kindly refer to the references for further information on this research and background on the Great Place to Work ${ }^{\circledR}$ model.

The Work Climate project revealed European trends on 
the quality of work, showing differences between member states that could not be expressed in a single parameter. The first explanation is due to the nature of the concept of quality: it is multidimensional and built on a wide range of components which interact with one another (intrinsic job quality, skills, lifelong learning and career development, gender equality, health and safety at work, flexibility and security, inclusion and access to the labor market, work organization and work life balance, social dialogue and worker involvement, diversity and non-discrimination and overall work performance).

The second explanation, and topic of this paper, is the multi-leveled-ness of the European Work Climate. One of the outcomes of the study is the robustness and equality of the model structure, throughout the dataset. However, different levels of perception appeared through the different countries, showing clear and consistent countries typologies. The data suggested three categories: the leading Scandinavian countries, the lagging Mediterranean countries and a mixed group in between.

The outcome was embarrassing for Great Place to

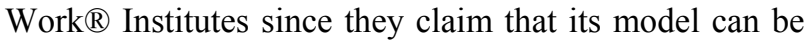
applied worldwide without cultural biases and in different economic contexts. True, Great Places to Work ${ }^{\circledR}$ are found everywhere, in 30 countries worldwide and in any economic sector. As the model is highly focused on the quality of management (Are they credible? Do they behave respectfully and fairly to employees?) And with data highly sensitive toward this factor, companies can become a great place to work $\AA$ despite their economic environment. This is great news for managers who want to establish an employer of choice status, but it provides no clue in explaining the multi-levelled ness of European economies.

The author, member of the EU Work Climate project group, suggested to apply an explicit phase wise development approach he successfully used in the development of the EU sponsored European Corporate Sustainability Framework.

In 2003, van Marrewijk et al. introduced a multiple level approach to Corporate Sustainability and Corporate Responsibility (CS-R). They "colored" a generic definition of CS-R into a sequence of more specific definitions matching the development, awareness and ambition levels of people and organizations: CS-R was either oriented to compliance; success and entrepreneurship; community or synergy. Each emerging orientation included and transcended the previous ones. These definitions of CS-R were framed in a more generic phase-wise development pattern, based upon the Graves' Level of Existence theory or Spiral Dynamics as it has been coined by Cowan and Beck (1996).

In 2004, in a Journal of Business Ethics publication, van Marrewijk described ideal type organizations, based upon four core value systems defined by professor Clare W. Graves. Per ideal type various organizational aspects were described briefly, such as the leadership style, governance and decision making issues and measurement format. As a summary, he developed the Transition Matrix, indicating the paradigm shifts per management discipline, as they have developed in each of the ideal type organization models.

Formulating the EU ambitions towards 2010 by itself emphasized the stretch between current (or traditional) and espoused business practices. The majority of companies seems to be traditionally oriented at managing their (human) resources, i.e. seeking optimum returns on their investments while focusing on efficiency and cost control, while pioneering and leading organizations are practicing with emerging stakeholder oriented business concepts.

This situation pointed us to the following questions: What type of economy has supported the more traditional approach to economic growth? What are the limits to such economies? Why should and how can companies and economic systems transform to more complex systems? And what type of economies is more adequate in achieving the goals of the European Union? One way or the other, the multilevel and multidimensional nature ensure that the diversity across the European Union can be fully taken into account.

Understanding the dynamics between and within economic systems is essential for European policy making, both at the supra and national level.

This paper introduces the Spiral Dynamics Theory and presents five ideal type economic systems. The last chapter discusses the consequences for international economic policy making.

\section{Ideal-Type Economic Systems Based on Spiral Dynamics}

Clare W. Graves' is the founder of the Emergent Cyclical Levels of Existence Theory. His successors, Beck and Cowan, renamed it "Spiral Dynamics" and successfully introduced Graves' academic achievements to a wider audience. As professor in psychology and a contemporary of Maslow, Graves was interested in the question how the mind (thus people and groups of people) processes reality. Based on extensive empirical research Graves concluded that mankind has gradually developed eight core value systems or "worldviews", so far. Each level of existence constructed around a core value system-provide its own hierarchy of needs. Values are considered as coping mechanisms to meet specific challenges and to structure institutions in order to influence behavior. A value system is a way of conceptualizing reality and encompasses a consistent set of values, beliefs and corresponding behavior and can be found in individual persons, as well as in companies and societies. A value system develops mainly as a reaction to specific environmental challenges and threats: the systems brighten or dim as life conditions 
(consisting of historic Times, geographic Place, existential Problems and societal Circumstances) change.

All entities-including organizations and economic systems-will eventually have to meet the challenges their context provides or risk the danger of oblivion or even extinction. If for instance societal circumstances change, inviting corporations to respond and consequently reconsider their role within society, it implies that corporations have to re-align their value systems and all their business institutions (such as mission, vision, policy deployment, decision-making, reporting, corporate affairs, etcetera) to these new circumstances. The quest to create an adequate response to specific life conditions results in a wide variety of survival strategies, each founded on a specific set of value assumptions and demonstrated in related institutions and behavior.

The development of value systems occurs in a fixed order: Survival; Security; Energy \& Power; Order; Success; Community, Synergy and Holistic life system. Each new value system includes and transcends the previous ones, thus forming a natural hierarchy (or holarchy). Please refer to Table 1, especially the first six rows, for an introduction on the Spiral Dynamic theory.

Having discussed the issue with both Christopher Cowan and Don Beck, the co-authors of Spiral Dynamics, the author has chosen for a pairing of value systems as fundaments of economic systems:

1) Pre-capitalist systems, based on Security and Power (purple and red)

2) Classical economic systems, based on Power and Order (red and blue)

3) Capitalist economic systems, based on Order and Success/Entrepreneurship (blue and orange)

4) Social Economic Systems, based on Success/Entrepreneurship and Community (orange and green)
5) Interdependent Economic System, based on Community and Synergy (green and yellow)

Ideal types 2 and 3 are resource oriented systems and ideal types 4 and 5 are stakeholder or multiple-focus, oriented systems.

Each emerging system transcends and includes the previous ones. More complex economic systems include elements of less complex systems. Comparing economic systems should never become a model contest - which one is the prettiest?-or a black and white discussion. It is more sensible to discuss why capitalism experiences difficulties in accepting the values of a social market economy. Or, what elements of capitalism should a market economy cherish and preserve in order to sustain its system.

Each presentation of an ideal type economic system briefly touches upon the underlying value systems, the dominant worldviews and related, often psychological explanations of its agents, which brings forth supporting institutional arrangements and policies.

\subsection{Pre-Capitalist Economic Systems, Based on Security and Power \& Energy}

\subsubsection{Introduction of its Value Systems}

The first three levels of existence mankind experienced are characterized as Survival, Security (bonding order) and Energy \& Power (powerful self).

Historically, loose tribes evolved to clans, seeking refuge in kinships, rituals, holy ancestors and mystical nature. The value system supporting Security can also be observed in the mother and child relationship, deep feelings of belonging, but also pride and attachment to the group identity. It color code is Purple.

Table 1. Summary of spiral dynamics.

\begin{tabular}{|c|c|c|c|c|c|c|c|}
\hline $\begin{array}{l}\text { Main } \\
\text { Themes }\end{array}$ & $\begin{array}{l}\text { Security } \\
\text { (Purple) }\end{array}$ & $\begin{array}{c}\text { Energy \& Power } \\
\text { (Red) }\end{array}$ & Order (Blue) & $\begin{array}{c}\text { Success \& Entre- } \\
\text { preneurship } \\
\text { (Orange) }\end{array}$ & $\begin{array}{l}\text { Community } \\
\text { (Green) }\end{array}$ & Synergy (Yellow) & $\begin{array}{c}\text { Holistic life } \\
\text { system } \\
\text { (Turquoise) }\end{array}$ \\
\hline $\begin{array}{l}\text { Environ- } \\
\text { ment }\end{array}$ & $\begin{array}{l}\text { A frightening } \\
\text { world }\end{array}$ & $\begin{array}{l}\text { Limitless challenges } \\
\text { about boundaries of } \\
\text { the territory and to be } \\
\text { dominant over self } \\
\text { and others within the } \\
\text { territory }\end{array}$ & $\begin{array}{l}\text { Ordered relationships } \\
\text { requiring legitimiza- } \\
\text { tion in order to ensure } \\
\text { stability and security } \\
\text { for the future }\end{array}$ & $\begin{array}{l}\text { Many viable alter- } \\
\text { natives for progress, } \\
\text { prosperity and } \\
\text { material gain since } \\
\text { change is the nature } \\
\text { of things }\end{array}$ & $\begin{array}{l}\text { The gap between } \\
\text { people and their } \\
\text { (material) possibili- } \\
\text { ties has become } \\
\text { disproportionately } \\
\text { large }\end{array}$ & $\begin{array}{l}\text { Complex problems } \\
\text { that cannot be } \\
\text { solved within the } \\
\text { current systems as } \\
\text { awareness of broad } \\
\text { interconnections } \\
\text { grows }\end{array}$ & $\begin{array}{l}\text { The consequences } \\
\text { of human actions } \\
\text { threaten the } \\
\text { planet's living } \\
\text { systems and } \\
\text { demand coordi- } \\
\text { nated effort }\end{array}$ \\
\hline Drive & Safety-driven & Exploitation-driven & Compliance-driven & Profit-driven & Care-driven & Systemic-driven & Holistic-driven \\
\hline Life force & $\begin{array}{l}\text { Physical and social } \\
\text { safety and security }\end{array}$ & $\begin{array}{l}\text { Conquering } \\
\text { domination }\end{array}$ & $\begin{array}{l}\text { Belief, moral duty } \\
\text { stewardship }\end{array}$ & $\begin{array}{l}\text { Achievement, } \\
\text { changeability }\end{array}$ & Belonging, idealism & Understanding & Interconnections \\
\hline Main focus & $\begin{array}{l}\text { Group/collective. } \\
\text { Bonding Order }\end{array}$ & $\begin{array}{l}\text { Individual/self } \\
\text { Powerful Self }\end{array}$ & $\begin{array}{l}\text { Group/collective, } \\
\text { Absolute Order }\end{array}$ & $\begin{array}{l}\text { Individual/self, } \\
\text { Enterprising Self }\end{array}$ & $\begin{array}{l}\text { Group/collective, } \\
\text { Egalitarian Order }\end{array}$ & $\begin{array}{l}\text { Individual/self, } \\
\text { Integrating Self }\end{array}$ & $\begin{array}{l}\text { Group/collective, } \\
\text { Holistic Order }\end{array}$ \\
\hline $\begin{array}{l}\text { Values } \\
\text { examples }\end{array}$ & $\begin{array}{l}\text { Reciprocity, } \\
\text { respect and } \\
\text { allegiance to- } \\
\text { wards elders, } \\
\text { mother love }\end{array}$ & $\begin{array}{l}\text { Courage, vitality, } \\
\text { strength, personal } \\
\text { respect, personal } \\
\text { power, rivalry, terri- } \\
\text { torial, intimidation, } \\
\text { hedonism, loyalty to } \\
\text { persons, assertive }\end{array}$ & $\begin{array}{l}\text { Clarity, discipline, } \\
\text { one truth, responsi- } \\
\text { bility, loyalty, duty, } \\
\text { guilt, conformity, } \\
\text { justice, obedience, } \\
\text { orderliness, stability, } \\
\text { clarity, one truth }\end{array}$ & $\begin{array}{l}\text { Results, reward, } \\
\text { image, quality, } \\
\text { innovation, produc- } \\
\text { tivity, creativity, } \\
\text { career advancement, } \\
\text { enterprising, control } \\
\text { personal esteem, } \\
\text { image, satisfac- } \\
\text { tion, competition }\end{array}$ & $\begin{array}{l}\text { Consensus, conflict } \\
\text { avoidance, team- } \\
\text { work, equality, } \\
\text { participation, hon- } \\
\text { esty and openness, } \\
\text { being a decent } \\
\text { person, harmony, } \\
\text { trust, love }\end{array}$ & $\begin{array}{l}\text { Insight, integrity, } \\
\text { learning, long-term } \\
\text { orientation, ability } \\
\text { to reflect, flexibility, } \\
\text { tolerance for uncer- } \\
\text { tainty and paradoxes } \\
\text { systems-thinking }\end{array}$ & $\begin{array}{l}\text { Inspiration, inter- } \\
\text { dependence, future } \\
\text { generations, ability } \\
\text { to forgive, wis- } \\
\text { dom, sufficiency, } \\
\text { responsible living }\end{array}$ \\
\hline
\end{tabular}


Freeing themselves from kinships and family ties, people gradually experienced ways of expressing themselves guiltlessly and selfishly, so as to find immediate pleasure and avoid shame in a world of domination, threats and ego. Power \& Energy-indicated with Red-can be easily recognized in feudal states, street gangs and war lords. Healthy Red can also be observed in top athletes and board of directors. It shows in perseverance when the going gets tough, in striving for victories and playing the power game. Unhealthy Red is often encountered in traffic (road rage), in large crowds (hooliganism), corporations ("rat" behavior) and among "party animals".

Red lacks the capacity for long term sequential thinking. They feel no guilt, only the need to gratify impulses and senses immediately. Individual persons tend to manifest these energies especially when they are young (set limits and they will test it!) or in adverse times (CEOs, admirals) or provoked and challenged to bring out the best they've got. These manifestations relate to an environment with limited possibilities, with a shortage of sources, provoking entities to fight in order to gain control and get their share.

\subsubsection{Features of a Pre-Capitalist System}

With reciprocity as one of the main characteristics of the Security system, economics in the early ages was based on barter, on the exchange of food or early division of tasks, such as carving stones or making artifacts. Slowly excess supplies among clan members and within little hamlets were exchanged at regional markets and gradually money was introduced to support the emerging trade relations. A systems of guilds supported skilled professionals and artists. However, political leaders where dominant in societies. In exchange for security pheasants were ordered to offer physical help to build roads for their armies, assist in constructing public buildings, such as cathedrals, or provide parts of their harvest to feed soldiers or replenish the stocks of the lords.

In his 20 year reign Ming emperor Zhu Di was responsible for renovating the Chinese wall and expanded it with more than $1.000 \mathrm{~km}$. To feed the million workers he assigned to widen and expand a canal system to allow hard wood freighters to ship grain and rice from the south to the north, which took another million workers. The jungles of nowadays Vietnam were stripped from teak wood to build over thousand of maritime vessels and treasure ships that sailed the oceans from 1421 to 1423, and colonized both coasts of the Americas, 70 years before the Europeans did. Last but not least, Zhu Di moved his capital to Beijing and built the Forbidden City.

These huge efforts, that took extensive planning and economic power, primarily emphasized the greatness of the emperor. The wall was meant to strengthen national security (Purple), but the opening of the Forbidden City with ambassadors of all relevant empires and kingdoms present, marked the stature of Zhu Di (Red). Maintaining and opening trade relations was a way to expand the tribute system for the emperor, not to exploit colonies for gold as the Europeans did many years later.

Gavin Menzies (2002): 1421, the year China discovered America.

We can still observe these pre-capitalist economies in countries such as Afghanistan, with strong tribal structures, or war torn and impoverished countries such as Dafur and Malawi. Within European countries this system tends to marginalize and can still be observed when people sell homegrown vegetables from small market gardens or backyards, or products manufactured as personal hobbies. Also alternative money systems (local exchange currencies) relate to this type, supporting a time-for-time exchange of goods, but primarily services.

\subsection{Classical Economic Systems, Based on Power \& Energy and Absolute Order}

\subsubsection{Introduction of an Emerging Value System}

When people learn to transcend the self, experience consequential thinking, they are able to live up to "higher ideals," find pride and fulfillment in their work and accept sacrifices now so as to obtain rewards later. New values emerged that matched a quest for order, meaning and purpose. Feudal states transformed to empires with strong bureaucracies and military power to control and stabilize societies. Nation states emerged, emphasizing their (purple) identities, icons for belonging and pride en newly won (red) energy to stand out and (blue) efforts to standardize legal system and so forth.

Christianity, communism, armies and bureaucracies represented Absolute Order, providing a master plan that puts people in their proper places. Impulses are controlled through discipline, guilt and punishments. The rightful authorities seek order and stability and succeed in making their people believe to sacrifice themselves for future rewards.

People "with a lot of blue" live by the book. They try to comply with the laws, regulations, procedures and agenda's that structure their lives. Life is relatively simple: for each problem there is a proven practice and a guidebook to help them solving it, step by step.

\subsubsection{Features of a Classical Economic System}

The grandeur and power of political leaders was envied by people who firstly succeeded in making fortunes in gradually growing money driven society, such as bankers, early industrialists and senior civil governors. Starting in the era of the renaissance up to today, new (business) leaders formed a new elite that purposefully arranged a political economic system that kept the "establishment" intact. As an old boys network, they took a pivotal position within society creating control functions to stabilize society and manage their economic sources in order to maintain their powerful position. When this system is 
dominant in society leadership is executed transparently, but when confronted with strong influences from emerging systems the powerful connections of leadership will hide under the surface, but the elite continue to safeguard their powerbase.

Leadership implies providing direction and maintaining stability. They will never themselves, nor allow others to "rock the boat!" If necessary leaders manipulate, pretend, divide and rule or play the boss. With support of sufficient blue, the behavior of leaders can be characterized as authoritarian and custodial ${ }^{1}$.

The archetype leadership activity is "managing": formulating top-down planning schemes and policy deployment, determining control systems and budgets and designing and maintaining procedures and a clear division of tasks.

Strong governments with often inefficient bureaucracies try to control the status of each individual linking its position in the hierarchy or stratified society. Nation wide there is a strong sense of moral duty.

Taylorism and related scientific management is typically linked to Order. Their principles of standardization, specialization, maximization, concentration and centralization are features according to which business and the entire economic system is run. Various quality management concepts supporting a resource orientation are commonly applied in both business and government.

Although industrialization is rapidly increasing, trade and handicrafts remain predominant in urban life, while agriculture and fishery are the principle activities in the country side. The majority of companies is family owned, maintaining a strong purple bond. Markets are relatively undeveloped, especially markets for exchanging production factors such as labor and capital. New job positions are hardly presented transparently, as cooptation via family connections is commonly preferred for. Also life long employment schemes answer perfectly to the circumstances in this economic system. Capital markets gradually emerge as cooperatives among those with needs.

Economic thinking focuses on production systems with a strong bias towards resource and technology-oriented issues. Governments allow business to create economies of scale and vertical integration. This growth strategy supports the power base of the establishment.

Governments tend to protect their industries against foreign takeovers, and are often willing to financially support them despite proven inefficiencies. American agriculture and airspace industries, Suez Gas in France, Telefonica in Spain and British Steel are but a few examples of sectors and companies receiving (financial) support from governments.

\footnotetext{
${ }^{1}$ Davis (1967): Authoritarian refers to the authority of the leader, and the custodial (paternalistic) on the organization as a whole securing the (basic) needs of the employees.
}

Furthermore, this system is characterized by the existence of old boys networks and various types of corporatism or business groups. Success in Power and Order is measured in terms of personal prestige and material wealth of the few.

Performance measurement is not commonly applied; if so, apart from tax obligations, it is not shared openly.

The classical economic system comes in three varieties, all rooted in the value systems of Power and Order. These are 1) the neo-mercantile Developmental States, 2) the communist plan economies and 3) the traditional economic system from which the capitalist system gradually evolved.

Developmental States, coined by Chalmers Johnson (1986), show evidence of intensive, interdependent collaboration between government, bureaucrats and industrialists, particularly in heavy industries, and a planning rational how to gain long term national welfare. It has been successfully applied in countries such as post war Japan, the Asian tigers (South Korea, Singapore and Taiwan) and, contemporarily, the BRIC countries (Brazil, Russia, India and China).

Post War Japan was forced by allied powers to transform its old pre-war industrial conglomerates (Zaibatsu) into corporate networks (Keiretsu), in order to break the power of the pre war establishment. Under the surface of change, the old structure remained in tact. Japanese bureaucrats at the Ministry of Trade and Industry (MITI) and business leaders rejected the philosophy of laissez-faire and free trade of open markets. To them, these concepts were little more than protection for the economically powerful exporters. The strategy of Developmental States is the denial of extant hierarchy of comparative advantage. In close collaboration with industrialists, Japanese bureaucrats used economic interventions effectively to foster the technological development, capacity growth, and competitiveness of targeted industries. With export industries booming with first cheap and later quality superior products, the Japanese economy has grown rapidly up to the end of the eighties. Emerging influences in the world economy and growing complexities crumbled the old boys network and deteriorated the effectiveness of state interventions.

In Europe we have observed this neo-mercantile variety to some extent in Nazi Germany and pre-war Italy.

The Plan Economies, applied by communist regimes, differed with the former in two aspects: The apparatchiks, the party bureaucrats running the planning system, were quite dominant and worked strictly top down, while the old boys network in for instance Japan exchanged complex information between public and private sector representatives while using market intelligence and price information in their planning approach. The communist's planning system was highly detailed but not as sophisticated. Despite remarkable achievements, the communist economies were less effective, especially on the world market, and resulted in extensive inefficiencies which 
ultimately jeopardized their existence.

We can observe the traditional economic system in all western economies, as governments and bureaucrats are hardly part of the establishment or their collaboration is not backed up by a sophisticated planning system. In Mediterranean countries such as France, Spain, Greece and Italy, this classical/traditional economic system is still dominant. France also has institutions that relate to the neo-mercantile tradition.

A common example of applying traditional thinking in all western economies is the exhaustive rewarding of CEO's: it is not market competition, as they say, but getting what they think they deserve, being the "top dogs" of their organizations, (un)consciously imitating the grandeur of former kings and emperors.

\subsection{Capitalist Economic Systems, Based on Order and Success \& Entrepreneurship}

\subsubsection{Introduction of an Emerging Value System}

With too much emphasis on values such as discipline, loyalty, duty, guilt, conformity, justice, obedience and orderliness the Order way attracts adverse effects such as:

- Limited problem solving capacity and reluctant creativity;

- Suffocating rules and procedures for companies and civilians;

- Planning and regulation is more important than the objective;

- One truth, one right way, always categorical.

When life conditions gradually changed, people boosted with Red energy could develop and adopt new competences, new ways in approaching new challenges, choosing new ambitions. Being born a "nickel" the "Enterprising Self" knows how to grow into a "dime", into something larger, gaining control over its destiny. Success is the new name of the game in an environment offering plenty opportunities to compete, win and make things better and better.

In Success multiplistic thinking evolved offering many options and choices. In Order, people compared to the standard, but with Success they benchmark themselves against competition and the number one. People centered in the value system of Success recognize change is the nature of things, creating new niches and introducing new technologies, enhancing life for many.

They work hard-preferably make others work hard for them-and risk time and money (not their life, as in Power) to achieve prosperity and material gain. They seek out the "good life" and abundance, rather than rewards hereafter. The expressions "keep up with the Joneses" and "if you can't make it, fake it" are typically Success and Entrepreneurship.

\subsubsection{Features of Capitalist Economic Systems}

Blue Order and Orange Success are the true fundaments of the capitalist system. It started off with Adam Smith's Wealth of Nations (1776), and was strengthened by academia such as David Ricardo (1817) and John Stuart Mill (1859). The "invisible hand" and the concepts of comparative advantages, resource allocation and "liberty" were major steps in the development of market oriented economies. With an enormous outburst of energy the capitalist approach was spread throughout economies. As with Schumpeter's "perennial gale of creative destruction" old establishments crumbled or are gradually losing their power. With disciples as Milton Friedman (Free to choose) the market economy based on free competition was presented as a new religion. It would bring prosperity to all people and countries alike. An "American dream" lies ahead for anyone who would "Go West" and put his pioneering spirit to work.

A typical description of the Success value system is the world presented with plenty of viable alternatives for progress, prosperity and material gain. People and organizations realize that change is in the nature of things and (personal) success the name of the game. Both people and organizations act in a calculated way while striving for autonomy and independence, seeking progress and success with the best solutions. If they are allowed to, they try to master nature and exploit its resources.

This description relate to a set of characteristics of the capitalist economic system or Anglo-American approach. They refer to leadership, resource allocation and governance structures.

The archetype role of leaders in a capitalist system is the Entrepreneur: discovering niches as opportunities for success, putting together new "combinations", creating and generating the necessary means and enjoying the fruit of their labor. Burton Klein's "Happy Warrior" and, again, Schumpeter's "creative destruction" are classic illustrations of the entrepreneurial drive behind capitalism.

This calculative attitude, seeking the best option among a variety of alternatives, supports the functioning of markets, allocating resources in the most efficient way. With its focus on prices, the capitalist system is very much cost oriented. Creating shareholder value is the ultimate aim. The Order fundament of Taylorism, scientific management and various (financial) control techniques have enhanced their focus on returns on investment and profit maximization (revenues versus costs) while continuously balancing costs and benefits. Their Success impulses increased their competitive competences, such as marketing and product development.

Along with enormous progress in transportation and information technology, the capitalist economic systems inevitable emerged into "globalization". In stead of organizing production capacities within a local hierarchy, companies decided to decentralize their production system to "low wage" countries or leave these activities to the market entirely. It has become a matter of tuning transaction versus productions costs. 
Due to innovative developments in information and transportation technologies, companies in the US, Europe, Japan, Korea and Taiwan were able to outsource parts of their production process to low wage countries. A simple shirt might have been produced in Vietnam, made of Turkish cotton, dyed in India, has Mexican buttons and Chinese pins and packaging method. A Singapore cargo ship transported it to the port of Rotterdam and during this trip the cargo changed ownership several times. This shirt is sold cheap, but contributes to profits anyway. Unfortunately the capitalist system hardly monitors the social consequences of this production system. The local farmer received hardly enough to finance a new harvest, Indian rivers are completely polluted, the working conditions in Vietnam are awful and the little girls that were sewing the shirt hardly get a wage at all. Local cultures are washed way by the icons of the global capitalized world.

The role of government and bureaucrats is simply to enable people and companies to compete freely and prevent market failures to occur. Based on a set of Order competences, the capitalist system provided the context for a Regulatory State, creating a level playing field for free competition through clear legislation and subsequent enforcement. This legal system ought to be effective and visible (law and order) rooting out everything that compromise the market mechanism. Additionally, the public sector must remain as small as possible.

Business' role in society is more or less independent and (a minimum level of) social welfare is the exclusive responsibility of the state.

Order was already purposeful and goals oriented, but through typically Success values such as image, quality, (process) innovation, productivity, creativity and being entrepreneurial, companies have become result-oriented. It reinforced the desire to compete and to become better.

The Order-Success value system resulted in a strictly fact-oriented approach to measuring performance. Success is primarily measured in terms of shareholder value, thus in money and commercial assets. Especially market share, growth figures, payout periods and returns on investments are crucial indicators to mark the results of their achievements.

The Anglo-Amercian character of capitalism is emphasized in the clear distinction between the owners of capital and management of corporations. The executive managers' prime goal is to guarantee the highest profits and thus best return on their invested capital. Management is subordinate to the owners' interests and they can be fired when they fail to achieve the expected results, or rewarded when successful.

We can observe the capitalist system in all countries worldwide, from tiny spots in African cities, expanding zones in China to dominant positions in the UK and the USA.

\subsection{Social Economic Systems, Based on Success/Entrepreneurship and Community}

\subsubsection{Introduction of an Emerging Value System}

The success of the entrepreneurial capitalist way gave rise to a new value system as the negative effects could no longer be managed adequately. With profits gained at the expense of the weaker, the capitalist system generates dropouts. Its supportive value system tends to elitism, as Success is inattentive to a fair distribution. With a hang to quantity and profits, instead of quality and durability, Success creates "consumerism" and a huge waste stream. Capitalist societies tend to exploit and ultimately jeopardize their (natural) resources. At the personal level, striving for success often becomes compulsive, leaving orangists no time to enjoy their fruits.

The Purple reciprocity and Orange accumulation of material wealth paved the way for Green redistribution of society's resources among all. The self is once more being sacrificed, but this time in a world where care, love and belonging are paramount, where everything is relative and "truth" is a matter of context and the group's needs. The Egalitarian Order, as this value system has been labeled by Cowan, liberates humans from dogma and greed, promoting a sense of community and unity. Solidarity is felt with the weaker and dropouts, victims of a system exploiting resources and causing an unequal distribution of material wealth.

People and organizations with a lot of Community-sense try to explore the inner beings of themselves and others. They refresh spirituality and seek to bring New Harmony. Generally Community is anti-dogmatic, and since everyone is unique, anti-labeling and anti-hierarchy, but highly tolerant.

\subsubsection{Features of a Social Economic System}

The Dutch "Polder" approach - introduced in the White House by former Dutch Prime Minister Wim Kok- and Tony Blair's "Third Way" are strongly rooted in the values systems Success and Community. They question the outcomes of capitalist societies but remain centered in a market economy approach.

The capitalist-socialist transformation is quite dramatic, as one can observe strong resentments in the political arena discussing it. Three features of the capitalist system are subject to major change:

- The democratization of power: the old establishment has finally lost its powerful position, as decision making must include the interests of all stakeholders;

- Market failures: free competition does not necessarily generate the best outcomes to all; Governments have to intervene in markets to improve their performance;

- Resource allocation: as efficiency does not neces- 
sarily include all costs, social issues are left to negotiations between social partners.

As the capitalist system focuses at managing resources and increasing shareholder value, the socialist market economy is primarily oriented at managing stakeholder interests: balancing the stakes of various groups in a market environment, of which the preconditions are set in the political arena or the negotiation table of social partners. As elites and establishments violate the sense of equality, especially regarding the distribution of wealth, and short term market arrangements jeopardize the interests of other stakeholders, such as employees, next generations and the ecological environment, new value systems emerge that inspire new institutions to make manifest a multi stakeholder approach.

In the level of development characterized as the Egalitarian Order or Community, the concept of an organization has changed. It is no longer regarded as an entity as such but as a group of people engaged in a process of organizing, of working together in trying to achieve common goals. It inevitably implies the involvement of all stakeholders, within and outside the organization. Community values, such as empathy, trust, kindliness and care, support competences enhancing the ability to involve everyone (engagement) and listen carefully (dialogue). In 2003, the author phrased it as follows: "The principle of Agency (autonomy, self-determination), the right to be and act according to ones awareness, capabilities and best understanding of its situation, is balanced by the moral obligation to be accountable for its impact on the environment. It is this principle of Communion that limits freedom when it interferes with the freedom of others."

In a socialist market economy resources are not exploited but cared for. In this system the exploitation of natural resources is counteracted with the ideology to protect and preserve ones habitat and those of other beings.

Employees are no longer considered resources and also customers are recognized as human beings. As Peter Drucker already noticed in 1952 "when hiring a worker, one gets a whole man," In addition to the physical and intellectual capacities, human beings tend to include its emotional and spiritual dimensions. These capacities allow persons to better understand one other, learn from each other, collaborate more effectively and create a two-way flow of information, turning top down telling what to do into proper conversations and dialogues with all those concerned.

The archetype leadership style in Community is "coaching" - the servant leader. The servant leader, a term coined by Robert Greenleaf, implies a state of being, not doing: the first and important choice a leader can make is the choice to serve life, without which one's capacity to lead is profoundly limited. Servant leaders enable professionals to grow and develop their talents. Instead of providing solutions (as in Order), leaders should allow employees to create the answers themselves.

With typical values such as consensus, conflict avoidance, teamwork, equality, participation, honesty, openness, being a decent person and harmony, decision making in the context of Community is an, often time consuming, group process. Once the decision is reached, the buy-in is guaranteed and implementation can be done quickly. This type of consensus oriented decision-making implies that a new type of corporate governance structure has emerged, including a new role of management, a flat organization structure and shareholder value being balanced against the interests of other legitimate stakeholders.

Corporations influenced by this value system invite representatives of various stakeholders to the negotiation table. The first example, often supported by government regulations, is the workers councils, with its members voted by their colleague employees. Ideally, management and workers discuss corporate strategies and ways to enhance workers conditions. Corporate wise or collectively per industry union representatives negotiate wage schemes and packages of labor conditions, which, after an agreement with employer associations, is made law applicable for the entire sector.

Being care driven, companies tend to take better care of the workers and professionals. Absenteeism caused by work stress and incidents or work practices causing (permanent) injuries, such as RSI, are not only a costly affairs from employers perspective, but at the personal level, cause situations that must be brought back to its absolute minimum.

The Dutch laws on labor conditions are strict, obliging for instance all organizations to monitor the wellness of its employees and take actions whenever the outcome does not match the proper norms.

A second example of the centeredness of employees is talent management and human resource development. Due to increased complexity, organizations must invest in various ways to enhance personal skills and competences. It makes sense business wise (Success), but also supports the personal growth and professional development of employees (Community). These activities also increase employee flexibility and employability, which support the functioning of the labor market.

Especially in situations of labor shortages, companies try to become "employer of choice". By practicing creating a culture of trust internally first, a company is much more authentic (and successful) in trying to create a culture of trust among suppliers and customers.

Having discussed, to some extent, the inequality of previous systems and the Rhineland ways of overcoming them, we now turn to the shortsightedness of markets and how socialist governments tend to counteract them.

In capitalist systems governments ought to support the 
functioning of markets, and the smaller the governmental claim on resources and capacities the better. In social(ist) economic systems governments' primal role is to counteract the negative consequences of the market mechanism. They levy the financial outcomes of markets via taxes and social premiums and redistribute incomes to various groups who come short in maintaining decent life conditions.

Furthermore governments apply social regulations to prevent exploitation of workers as we have seen in extensive laws in enhancing labor conditions.

Governments stay at arm length when social partners, (employers - and employee associations) negotiate wages schemes, labor conditions and the functioning of markets in general. If requested governments such as in the Netherlands can lift collective agreements to law and made applicable to entire industries.

In addition to income policies and labor markets, socialist governments are inclined to influence markets that tend to favor specifics interests at the expense of others, such as natural monopolies in energy and telecom.

Redistributing up to $65 \%$ of BNP, the scale and impact of governments in social economic systems is much larger than in previous systems. The sheer size of governments has made them significant motors in their national economies. However, the adverse effects of rigid bureaucracies, has also burdened socialist governments as the cause of stagflation.

Socialist's success is measured in terms of the quantitative as well as the qualitative impact for all stakeholders involved, including groups who do not take part in economic production or distribution. The socialist dashboard is much larger and more complex than the one of the capitalist system.

\footnotetext{
"God create the earth... and the Dutch the Netherlands". This American expression refers to the century old situation of Dutchmen commonly reclaiming low-lying stretches of land from a body of water by building dikes and applying various techniques to manage the level of water within so called "polders". A typical governance structure emerged in which all stakeholder participated expressing their desired water level and their financial commitment, enabling authorities to balance the various interests and to achieve the compromised goals. The polder metaphor is used by the Dutch and foreigners alike to express decision making process based on consensus.

In the Netherlands, unions have often tempered their requests for a raise of wages to meet other social goals and prevent a frustration of long term economic perspectives. This situation was the fundament of the Dutch Miracle with respect to economic growth and the smooth transition towards a service oriented economy.
}

The essence of the social economic system is the ability and willingness of talking together and being collectively responsible for the choices made. The socialist system creates fora to discuss complex dilemmas such as being pragmatic or ethical, short-term profit oriented or sustainable. With all stakeholders present in the debates interests are expressed and respectively balanced, but sustainable solutions are hardly found.

We can observe this system as dominant in Continental Europe and especially the Netherlands and Scandinavian countries.

\subsection{Interdependent Economic System, Based on Community and Synergy}

\subsubsection{Introduction of an Emerging Value System}

Trying to be a nice, loving and decent person, are highly regarded qualities in Community. Conflict avoidance, however, also have negative consequences. With criticism smothered by love and judgments made relative to the situation at hand, decision-making risk non-functional and abstract outcomes.

Using each other's qualities for mutual growth, Community is able to create good learning conditions. However, the aura of an expert is badly regarded: consensus is more important than expertise and incompetence is not a reason to be laid off. With rising complexity levels, Community does no longer provide the ultimate solutions to the problems at hand. Furthermore, equality and consensus building may lead to pooling of ignorance.

Being confronted by chaos in a world at-risk, typical Community features such as the lack of leadership and expertise and the emotional and economic cost of caring are important arguments to develop new ways to cope with the ever increasing complexity of challenges.

Comprehension, understanding and connectedness are the buzzwords of Synergy. A person and organization centered in Synergy, express itself, but never at the expense of others or the earth. They will not say: "These people can't cook", but "This food is not of good taste".

In Synergy there is room for authenticy, since internal motivations matter a lot. Existentialism is strong.

People with values associated to Synergy can blend conflicting "truths", for it is able to see more colors and uses more senses at the same time. By focusing on functionality and applying competencies to get buy-in from others, Synergy is able to create win-win options and breakthrough solutions, seeking self-interest without doing harm to others and nature.

People dominantly centered in Synergy understand that the complexity of today's world cannot be solved within the current systems, as their awareness of broad interconnections grows. They recognize the inevitability of nature's flows and seek ways to accommodate "natural design". Understanding interconnectivities in all Wilberian quarters, seeking to grasp the very essence of their presence and by having created flexibility through breaking up structures into network organizations, people start to support all life in the most natural, sustainable, and 
fitting ways.

In order to meet its drive, to be, to learn and to discover, persons with a lot of Synergy function best in a network with a strong sense of direction, while demanding flexibility and open systems. Values such as insight, long-term orientation, ability to reflect and tolerance for uncertainty and paradoxes support the drive for self-development and boost people's ability to learn and apply knowledge. They are able to learn from any source. With a mind that quickly wanders, they have difficulty in maintaining focus.

\subsubsection{Features of an Interdependent Economy}

The social (ist) economic system is still rooted in capitalist practices, with political leaders mitigating its outcomes primarily through income redistribution. Due to a strong Order dominance they believe they can construct an ideal society. Dutch parliamentary history shows various examples of launching growth policies in the expectation that this will fulfill the needs of people. Unfortunately, the majority of these interventions have failed to meet its targets, fueling the capitalist propagandists and often causing a shift in parliamentary power in favor of the right wing conservatives.

Blue linear thinking can not serve as a construction philosophy, a blue print for contemporary needs. Being able to better understand the subtleties of human nature (Community) and system dynamics (Synergy), the successors of the hard core socialists create room for organic growth, by allowing nature, structures and society to unfold itself. It seeks to facilitate the emergence of a natural design.

Indeed is there a future for a socialist politician? Is there a way out in the Anglo-Saxon vs. Socialist Market economy debate? What are the pitfalls that caused failure and what values and what competences do we need to create new institutions in line with the envisaged Interdependent Economy?

Community consensus building hardly results in innovative breakthroughs and sustainable solutions. Community lacks vision, lacks leadership to match collective needs with stakeholder interests and personal ambitions. Synergy possesses these qualities. Therefore one must expect that the interdependent economic system will find ways to overcome current challenges in western social economies.

A private initiative in the Netherlands, launched by a.o. McKinsey, conducted the largest Dutch online survey ever, taking place in September/October 2006 and 2008. More than 170,000 inhabitants, being a representative sample of the Dutch society, took 21 minutes of their time to respond to current issues.

The Dutch expressed a strong desire (90\%) to attain a society build on solidarity, modesty and oriented towards quality of living. There is a wide support for measures stimulating growth of prosperity and simultaneously help achieve the desired organization of society. They strongly support new economic reforms as long as this does not increase the pressure on the environment. Examples are a more flexible labor market, working at home, accept restrictions on deducting mortgages and intensify inservice training.

Unfortunately, confidence in government's policies and the authorities' execution thereof is very low (25\%). Dutch citizens are very critical to the content of political parties, as they seem to root in traditional systems, thus unable to lead the Netherlands into the new era. (www. 21minuten.nl)

The Interdependent Economic System seems to aim directly at the fulfillment of needs of all people. In addition to socialist redistribution policies, the new system seek to align vision with personal commitment, balance long term interests with short term needs and harmonize ideology with pragmaticism. The life conditions that provoke Synergy to emerge are adequately matched by new ways sublimating "either - or" and "win - loose" arrangements.

Larger organizational entities are transforming - or breaking up - into network structures, demonstrating the drive behind Synergy. The Hollywood movie scene is a good example of a once highly successful oligopoly which broke up in numerous small professional clusters, who work together in a network for the duration of a project. Not far from Hollywood, in Silicon Valley, a network structure emerged bottom up, as independent professionals clustered into networks, creating the necessary competences to meet the challenges facing Synergy. Inertia transformed to flexibility, creating room for new strategies, new approaches to running economic activities resulting in improved performance levels.

Redistribution policies often resulted in pampering groups in need, stigmatizing their position as victims of the market economy. Interdependence, aligning the principles of agency and communion at a more complex level, emphasizes personal accountability or responsibility and acting accordingly. Interdependent economies educate those in need to reshape their futures. In popular terms: "when hungry, learn and enable them how to fish, instead of providing them just a fish".

The archetype leader in Yellow is the "Emergent Leader'. He or she authentically connects visionary qualities to a practical and personal approach and is able to link the various qualities of previous contexts into one effective and coherent approach. Emergent leadership lifts people, organizations and societies to levels where adequate answers can be developed to meet current challenges. It supports the sublimation, the transition of living entities to emerging levels of existence.

Leadership as defined in terms of Synergy is no longer confined to what people do, but grounded in who people are. An authentic choice to serve life increases ones capacity to lead by allowing life to unfold through you. The 
hierarchy between the leader and the led remains healthy: leadership is never dominating or abusing raw power. The leadership potential can be developed in everyone. It implies identifying the personal responsibility and the alignment between one's personality and ambitions with one's role within the network. Therefore, essentially, leadership is about learning how to shape the future.

Marketing as a concept is 60 years old. Human resource management became popular since the early nineties. What will be a new management discipline? "Synnovator", coined by the Center of Human Emergence, makes a good chance. This notion means to interconnect and vitalize. Companies explore new ways of cooperation and strategic partnership, both horizontally and vertically. By effectively working together with internal and external stakeholders, thus tapping into their competences and capacities, organizations find new opportunities to boost their performance. This time with respect to the triple bottom line: people, planet and profits.

Companies with a lot of Synergy tend to chose for a "people first strategy". They act as if they say: "We take care of the people. Our people take care of the business." They successfully allow professionals to be who they are and bring out the best they can. This way, highly skilled workers are able to create a sense of flow and achieve productivity levels which are unheard of in previous circumstances. According to research conducted in the USA, UK and Brazil, the very best Great Places to work $\AA$, being also listed at stock markets, score a four times higher financial growth than the average stock prices. Similar conclusions were drawn by Jim Collins in his best selling management book "Good to Great".

The Synergy value system is emerging rapidly at the personal and corporate level. Unfortunately, characteristic institutions of the interdependent economic system remain hypothetical. However, we can sketch the outlines of this approach:

- The scale of governments will decline again, as ministries no longer feel themselves being representatives of a particular stakeholder group, but act in the interest of the whole, while applying a better understanding of system dynamics;

- Bureaucracies, law enforcements and ministerial responsibility will be organized in more sophisticated manners;

- (Municipal) Authorities pro-actively support the concept of "great places to live", while collaborating with dedicated private and social institutes providing education, (health) care, safety, housing et cetera.

- Governments, social partners, individual corporations and NGO's work together intensively, exchanging information and using each others expertise to create breakthroughs in improving the quality of life for all;

- Governments and social partners should guarantee work protection in stead of job protection, empha- sizing each others' role in taking personal responsibility in improving ones future opportunities;

- Social security systems are not focused at income distributions alone, but emphasize the inclusion of those in needs in social communities and economic systems. Kennedy's statement: “Ask yourself what you can do for your country, in stead of what your country can do for you", gets a new dimension.

- As globalization involves the whole world, supra national institutes must be initiated to meet its challenges, not to protect particular interests at the cost of others.

We can observe the early stages of this system as emerging in the Netherlands and Scandinavian countries.

\section{Consequences for International Economic Policy Making}

This paper described various economic systems that are aligned with their (historical) contexts, their challenges and ambitions. The models can be placed in a specific sequence of development, creating an organic flow of macro economic institutions. Figure 1 tries to summarize these models as stages of development, each model including two subsequent and dominant value systems. The color codes have been introduced in Table 1 . The more complex, recently emerged systems transcend and include the less complex ones, the ones to their left, while the basic systems tend to marginalize as complexity emerges. We still tend to see the reminiscents of old systems, but their importance is decreasing.

Policy makers cannot choose from a menu card which system they like best. One cannot skip development levels. We have observed the troubles that occur when Afghani economic activities functioning at subsistence and pre-capital levels are forced into modern capitalist economies. It doesn't make much sense when Italian Mediterranean bureaucrats study Danish experiences.

Their first challenge is to transform into the next level. This is difficult enough as it is.

Even when traditional policies, approaches and economic structures fail to deliver improvements, in spite of the rising awareness that current institutions are no longer in tune with changing circumstances, it still isn't easy to adapt to new structures, new institutions, creating a new coherent model.

It helps to understand system dynamics. As a summary, Table 2 presents macro economic characteristics, structured according Spiral Dynamics.

The main questions arise, however, do political and economy leaders have the guts to move ahead, challenging the "ceilings" and collaborating with pioneering spirits.

Asking oneself if Europe's economic systems are converging to a particular level is implicitly raising the 


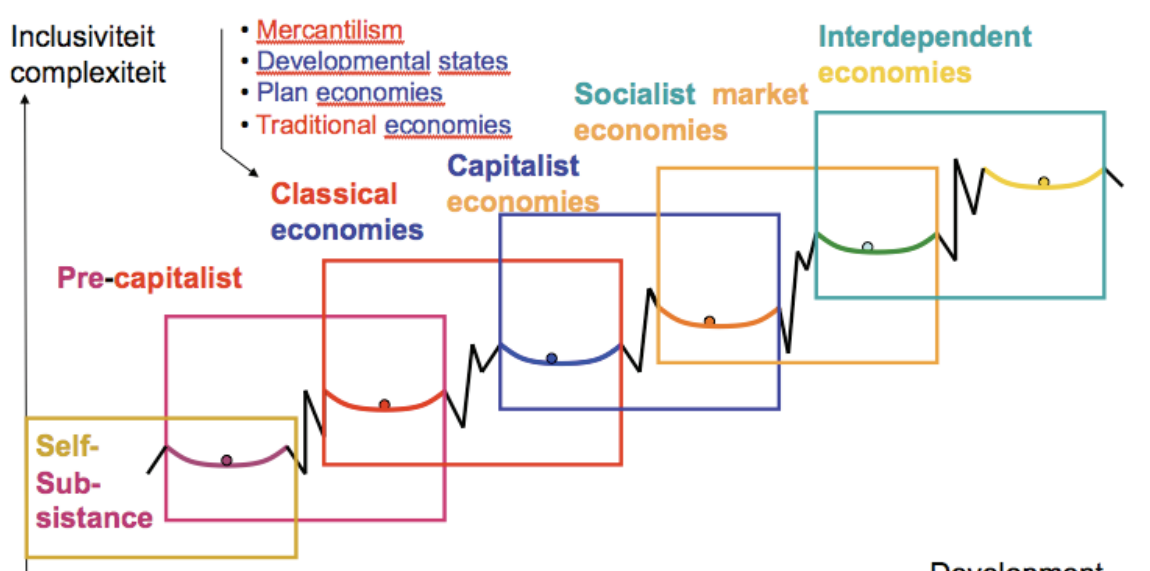

Development

Degrees of Freedom

Figure 1. Phase wise development of economic systems.

Table 2. Macro characteristics inspired by spiral dynamics.

\begin{tabular}{|c|c|c|c|c|c|c|c|}
\hline Main Themes & $\begin{array}{l}\text { Security } \\
\text { (Purple) }\end{array}$ & $\begin{array}{c}\text { Energy \& Power } \\
\text { (Red) }\end{array}$ & $\begin{array}{l}\text { Absolute Order } \\
\text { (Blue) }\end{array}$ & $\begin{array}{l}\text { Success \& Entre- } \\
\text { preneurship } \\
\text { (Orange) }\end{array}$ & $\begin{array}{l}\text { Community } \\
\text { (Green) }\end{array}$ & $\begin{array}{l}\text { Synergy } \\
\text { (Yellow) }\end{array}$ & $\begin{array}{l}\text { Holistic life system } \\
\text { (Turquoise) }\end{array}$ \\
\hline Scope & $\begin{array}{l}\text { We are but a small } \\
\text { and modest part of } \\
\text { the world, given to } \\
\text { us by the Gods, the } \\
\text { natural spirits and } \\
\text { our ancestors and } \\
\text { should be left } \\
\text { intact }\end{array}$ & $\begin{array}{l}\text { The world is there to } \\
\text { conquer, or at least } \\
\text { control or safeguard } \\
\text { its scares and vital } \\
\text { resources }\end{array}$ & $\begin{array}{l}\text { The world must be } \\
\text { stabilized to main- } \\
\text { tain order (and } \\
\text { maintain the current } \\
\text { establishment and } \\
\text { balance of power) }\end{array}$ & $\begin{array}{l}\text { The world occurs at } \\
\text { the local, national } \\
\text { and globalized } \\
\text { level, but is primar- } \\
\text { ily restricted to } \\
\text { economic parame- } \\
\text { ters and opportuni- } \\
\text { ties }\end{array}$ & $\begin{array}{l}\text { The world is one } \\
\text { village, a brother- } \\
\text { hood of man; has } \\
\text { one climate and has } \\
\text { no other place to go }\end{array}$ & $\begin{array}{l}\text { The social and } \\
\text { environ-mental } \\
\text { degradation are } \\
\text { inevitable when } \\
\text { mankind is not able } \\
\text { to act accor-ding a } \\
\text { systemic under- } \\
\text { standing of the } \\
\text { whole }\end{array}$ & $\begin{array}{l}\text { Interdependency. } \\
\text { Each person or } \\
\text { organization there- } \\
\text { fore has a universal } \\
\text { responsibility } \\
\text { towards all other } \\
\text { beings, both present } \\
\text { and future genera- } \\
\text { tions }\end{array}$ \\
\hline $\begin{array}{l}\text { Dominant } \\
\text { political } \\
\text { institution }\end{array}$ & Tribes, warlords & $\begin{array}{l}\text { Feudal States, Tribu- } \\
\text { tary systems }\end{array}$ & $\begin{array}{l}\text { Empires, Nation } \\
\text { States, early de- } \\
\text { mocracies }\end{array}$ & $\begin{array}{lr}\text { NATO, } & \text { Security } \\
\text { Council, } & \text { Top } \\
\text { X-Roundtable }\end{array}$ & $\begin{array}{lr}\text { European } & \text { Union, } \\
\text { United } & \text { Nations, } \\
\text { UNTAD } & \end{array}$ & $\begin{array}{l}\text { Supranational } \\
\text { governance, e.g. } \\
\text { International Court } \\
\text { of Justice }\end{array}$ & Not known yet \\
\hline $\begin{array}{l}\text { Style of } \\
\text { decision } \\
\text { making }\end{array}$ & $\begin{array}{l}\text { The words of the } \\
\text { elder; the in-crowd }\end{array}$ & $\begin{array}{l}\text { Authoritarian; dicta- } \\
\text { torship }\end{array}$ & $\begin{array}{l}\text { Procedural, top } \\
\text { down decision } \\
\text { making and policy } \\
\text { deployment }\end{array}$ & $\begin{array}{l}\text { Top down and } \\
\text { bottom up; negotia- } \\
\text { tions }\end{array}$ & $\begin{array}{l}\text { Bottom Up; Con- } \\
\text { sensus principle: } \\
\text { everyone } \\
\text { counts }\end{array}$ & $\begin{array}{l}\text { Consent principle, } \\
\text { anyone with a } \\
\text { valuable contribu- } \\
\text { tion counts }\end{array}$ & $\begin{array}{lr}\text { All } & \text { information } \\
\text { counts, } & \text { including } \\
\text { from } & \text { spiritual } \\
\text { entities } & \end{array}$ \\
\hline $\begin{array}{l}\text { Main stake- } \\
\text { holders }\end{array}$ & Elders & $\begin{array}{l}\text { Old boys networks, } \\
\text { elite, powerful ones }\end{array}$ & Legal authorities & $\begin{array}{l}\text { Finance, owners and } \\
\text { industrialists }\end{array}$ & $\begin{array}{l}\text { Civilians, employ- } \\
\text { ees, deprived groups }\end{array}$ & $\begin{array}{l}\text { All relevant stake- } \\
\text { holders }\end{array}$ & All living creatures \\
\hline $\begin{array}{l}\text { Role and size } \\
\text { of govern- } \\
\text { ment }\end{array}$ & $\begin{array}{l}\text { Emerging local } \\
\text { authorities, around } \\
\text { the elders }\end{array}$ & $\begin{array}{l}\text { Supporting staff of } \\
\text { the ruler and en- } \\
\text { forcement (like the } \\
\text { mandarins in old } \\
\text { China) }\end{array}$ & $\begin{array}{l}\text { Dedicated bureauc- } \\
\text { racy designing and } \\
\text { enforcing regula- } \\
\text { tions }\end{array}$ & $\begin{array}{l}\text { Public agencies, } \\
\text { maintaining a level } \\
\text { playing field for } \\
\text { competition }\end{array}$ & $\begin{array}{l}\text { Large bureaucracy } \\
\text { supporting redistri- } \\
\text { bution processes }\end{array}$ & $\begin{array}{l}\text { Smaller but dedi- } \\
\text { cated government } \\
\text { officials conducting } \\
\text { new societal devel- } \\
\text { opments }\end{array}$ & $\begin{array}{l}\text { Resilient network of } \\
\text { government institu- } \\
\text { tions supporting the } \\
\text { needs of the whole. }\end{array}$ \\
\hline $\begin{array}{l}\text { Dominant } \\
\text { strategy }\end{array}$ & $\begin{array}{l}\text { Providing security } \\
\text { for levying taxes }\end{array}$ & $\begin{array}{l}\text { Supporting emerging } \\
\text { markets and boosting } \\
\text { economic activities }\end{array}$ & $\begin{array}{l}\text { Policy deployment; } \\
\text { the constructive } \\
\text { society }\end{array}$ & $\begin{array}{l}\text { Level playing field; } \\
\text { supporting global- } \\
\text { ized economies }\end{array}$ & $\begin{array}{l}\text { Negotiation fora } \\
\text { with stakeholder } \\
\text { representatives }\end{array}$ & $\begin{array}{l}\text { Creating break- } \\
\text { thoughts in themes } \\
\text { that endanger } \\
\text { societies }\end{array}$ & $\begin{array}{l}\text { Supporting habitats } \\
\text { for the different } \\
\text { needs }\end{array}$ \\
\hline $\begin{array}{l}\text { Example: } \\
\text { orientation } \\
\text { towards } \\
\text { sustainability }\end{array}$ & $\begin{array}{l}\text { Maintain what is } \\
\text { there already, do } \\
\text { not alter the cur- } \\
\text { rent state }\end{array}$ & $\begin{array}{l}\text { Constructing large } \\
\text { statues, castles, } \\
\text { cathedrals, mauso- } \\
\text { leums and other } \\
\text { buildings expressing } \\
\text { the grandeur of the } \\
\text { leaders, the capitals, } \\
\text { etc }\end{array}$ & $\begin{array}{l}\text { Sustainability } \\
\text { implies a system of } \\
\text { legal rules and } \\
\text { procedures enforc- } \\
\text { ing people how to } \\
\text { behave and how } \\
\text { processes should be } \\
\text { run }\end{array}$ & $\begin{array}{l}\text { Sustainability is left } \\
\text { to market forces that } \\
\text { will impact social, } \\
\text { ethical and eco- } \\
\text { logical aspects into } \\
\text { business operations } \\
\text { and decision-ma- } \\
\text { king, provided it } \\
\text { contributes to the } \\
\text { financial bottom } \\
\text { line }\end{array}$ & $\begin{array}{l}\text { Sustainability } \\
\text { implies the balanc- } \\
\text { ing of economic, } \\
\text { social and ecologi- } \\
\text { cal concerns, in- } \\
\text { cluding initiatives } \\
\text { that go beyond legal } \\
\text { compliance and } \\
\text { profit considera- } \\
\text { tions }\end{array}$ & $\begin{array}{l}\text { Sustainability } \\
\text { implies a search for } \\
\text { well-balanced, } \\
\text { functional solutions } \\
\text { creating value in the } \\
\text { economic, social } \\
\text { and ecological } \\
\text { realms of corporate } \\
\text { performance, in a } \\
\text { synergistic, } \\
\text { win-together ap- } \\
\text { proach with all } \\
\text { relevant stake- } \\
\text { holders }\end{array}$ & $\begin{array}{l}\text { Sustainability is } \\
\text { fully integrated and } \\
\text { embedded in every } \\
\text { aspect of the soci- } \\
\text { ety, aimed at con- } \\
\text { tributing to the } \\
\text { quality and con- } \\
\text { tinuation of life of } \\
\text { every being and } \\
\text { entity, now and in } \\
\text { the future }\end{array}$ \\
\hline
\end{tabular}


question if Europe offers uniform life conditions and value patterns that would allow all economies to adapt similar approaches. Unfortunately this is not the case. Brussels and the representatives of individual economies must live with this situation and must learn to turn it into an asset. At the same time it must support the emergence of modern institutions in response to the challenges of modern day economics due to the international systemic crises, such as climate changes, food and water shortages and the economic instability.

\section{Acknowledgements}

I thank people who commented on earlier drafts or presentations of this paper.

- Wilbert van Leijden en Paul Zuiker, authors of "Nederland op doorbreken"

- The people attending my lecture at the Rotterdam School of Management on this subject, including prof.dr. Gerard Zwetsloot, dr. Dirk van Dierendonck and dr. Andre de Waal;

- The Rhineland workgroup in the Netherlands, including professor Matthieu Weggeman;

- Associates of the Center of Human Emergence and Synnervate, such as Peter Merry and Morel Fourman

- Co-founders of Corporate Dynamics, being experts on Value management;

- Professor John Groenewegen, my former professor on Institutional Economics and Economic Systems, Erasmus University Rotterdam.

- Guido Enthoven, director of IMI-Instituut voor Maatschappelijke Innovatie

\section{References}

[1] D. Beck and C. Cowan, "Spiral dynamics," Blackwell Publishers, 1996.

[2] T. van den Brink and F. van der Woerd, "Industry specific sustainability benchmarks: An ECSF pilot bridging corporate sustainability with social responsible investments," Journal of Business Ethics (forthcoming), 2004.

[3] C. Johnson, "MITI and the Japanese miracle: The growth of industrial policy, 1925-1975," 1986.

[4] J. C. Collins and J. I. Porras, "Built to last successful habits of visionary companies." New York: HarperCollins Publishers, 1997.

[5] T. W. Hardjono, "Ritmiek en Organisatiedynamiek: Vierfasenmodel," Kluwer, 1995.

[6] T. W. Hardjono and P. de Klein, "General introduction to the European corporate sustainability framework," Journal of Business Ethics (forthcoming), 2004.

[7] R. S. Kaplan and N. P. David, "the Balanced scorecard: Translating strategy into action," Harvard Business School
Press, 1996.

[8] W. van Leijden and P. Zuiker, "Nederland op doorbreken: een vernieuwend perspectief voor een land in crises," Emergent Publishing, 2007.

[9] M. van Marrewijk and T. W. Hardjono, "The social dimensions of business excellence," Corporate Environmental Strategy, Vol. 8, No. 3, 2001.

[10] M. van Marrewijk, "Concepts and definitions of corporate sustainability," Journal of Business Ethics Vol. 44, Nos. 2 and 3, May 2003.

[11] M. van Marrewijk and M. Were, "Multiple levels of corporate sustainability," Journal of Business Ethics, Vol 44, Nos. 2 and 3, May 2003.

[12] M. van Marrewijk and T. W.Hardjono, "European corporate sustainability framework for managing complexity and corporate change," Journal of Business Ethics, Vol. 44, Nos. 2 and 3, May 2003.

[13] M. van Marrewijk and Timmers, "J. human capital management," Journal of Business Ethics, Vol. 44, Nos. 2 and 3, May 2003.

[14] M. van Marrewijk, "European corporate sustainability framework," International Journal of Business Performance Measurement, Vol. 5, Nos. 2 and 3, 2003.

[15] M. van Marrewijk, W DeCleyn, I. Wuisman, et al., "A developmental approach to business excellence," Journal of Business Ethics (forthcoming), 2004.

[16] M. van Marrewijk, "The social dimension of organizations: Recent experiences with Great Place to work ${ }^{\circledR}$ assessment practices," Journal of Business Ethics (forthcoming), 2004.

[17] M. van Marrewijk and H. M. Becker, "The Hidden hand in cultural governance: the case of humanities' ten year period of transformation," Journal of Business Ethics (forthcoming), 2004.

[18] A. Maslow, "Toward a psychology of being." Van Nostrand Reinhold, 1982.

[19] J. Wempe and M. Kaptein, "The Balanced company: A theory of corporate integrity," Oxford University Press, 2002.

[20] K. Wilber, "A theory of everything: An integral vision for business, politics, science and spirituality," Shambhala, 2000.

[21] K. Wilber, "Sex, ecology, spirituality: The spirit of evolution," Shambhala, 1995.

[22] F. van der Woerd and T. van den Brink, "Feasibility of a responsive business scorecard-a pilot study," Journal of Business Ethics (forthcoming), 2004.

[23] World Business Council for Sustainable Development WBCSD Meeting Changing Expectations. Corporate Social Responsibility. New York: WBCSD, 1999.

[24] World Business Council for Sustainable Development WBCSD Corporate Social Responsibility: Making Good Business Sense. Geneva: WBCSD, 2000. 


\section{Abbreviations}

CS-R Corporate Sustainability and Responsibility

EU European Union

ECSF European Corporate Sustainability Framework

IEL Institute of Labor Studies, Esade Business

ECLET Emerging Cyclical Levels of Existence Theory

School 